\title{
A Survey on Satisfaction of Type 2 Diabetes Patients with Different Demographic Variables to Medical Services
}

\author{
Jui-che Tu ${ }^{1}$, Yi-Lin Lee ${ }^{1, *(1)}$ and Feng-Jung Nien ${ }^{2}$ \\ 1 Graduate School of Design, National Yunlin University of Science \& Technology, Yunlin 64002, Taiwan; \\ tujc@yuntech.edu.tw \\ 2 Subdivision of Endocrinology and Metabolism, Department of Internal Medicine, National Taiwan \\ University Hospital Yun-Lin Branch, Yunlin 64002, Taiwan; fj.nien@gmail.com \\ * Correspondence: cacaca710@gmail.com
}

Received: 21 February 2019; Accepted: 27 March 2019; Published: 29 March 2019

\begin{abstract}
Taking Type 2 diabetes as the research object, and through questionnaire interviews, this study sought to determine the degree of satisfaction of patients with different attributes with medical services according to the distribution of demographic variables. Finally, the statistical results were taken as the reference basis for medical personnel to provide care to patients. Regarding the questionnaire survey, the questionnaire items were designed through face-to-face interviews aiming at their medical treatment process, thus, patients could truly reflect their feelings. This study used the SPSS statistical software (IBM, Armonk, New York, NY, USA) for analysis, and the results show that: (1) Patients of different genders had different degrees of satisfaction with medical services. (2) The difference in age, monthly disposable income, occupational category, and education level had no significant effect on service satisfaction. (3) The research subjects were all on the high side regarding their satisfaction with the service provided by medical facilities. This study is a pilot study, and it is hoped it will be used as a guideline for improving patient care quality in the future, thus, reducing the occurrence of diabetic complications through better medical care. The long-term goal is to continuously improve care and medical service quality, thus, reducing the waste of medical resources.
\end{abstract}

Keywords: demographic variable; diabetes mellitus type 2; satisfaction survey

\section{Introduction}

With the progress of medical science, technology, and the economy, coupled with changes in eating habits and static lifestyle, diabetes has become one of the most important global public health issues in the 21st century. According to World Health Organization statistics [1], there were 410 million adults worldwide suffering from diabetes in 2016, the global diabetes prevalence rate will double from $4.7 \%$ to $8.5 \%$, and the number of patients worldwide is expected to increase to 592 million by 2035, and it is estimated that the number of adults suffering from diabetes will rise to over 640 million by 2040. Most of them are Type 2 diabetes patients. The causes of the disease are not only congenital genetic effects, but also lifestyle [2], which can be controlled by early diagnosis, active treatment, and lifestyle changes [3]. Patients with diabetes have many needs, such as diet, medical behavior, drug therapy, and related knowledge [4]. Relevant diabetes prevention and control organizations also suggest that care teams should consider the patients' feelings and satisfaction with medical services [5].

Ever since Taiwan's National Health Insurance was implemented in 1995, there have been significant increases in medical resources, medical institutions and personnel, and medical-care seeking behaviors of the general public. In addition to the National Health Insurance, there are also two other completely different healthcare systems in Taiwan: traditional Chinese medicine and 
Western medicine. There are also folk therapies and a large number of pharmacies in neighborhoods. It is a common phenomenon that the various healthcare systems may replace one another, and as a result the Taiwanese people have their own opinions on disease perception, interpretation, and medical-care seeking behaviors. Due to the unique medical environment in Taiwan, it is impossible to interpret the general public's behavior patterns entirely from the perspective of Western studies. In general, Western studies use a multivariate model, such as multiple medical-care seeking, family as a unit, etc. However, residents in different areas of Taiwan have developed different medical-care seeking behaviors according to the differences in their environment and socioeconomic status [6]. All in all, although there are sufficient medical resources in Taiwan, an urban-rural gap still exists. Taking the case in this study for example, the statistical data from the Taiwan Medical Association show in 2018 that there were approximately 45 physicians per 10,000 residents in the capital, Taipei City. However, Yunlin County has only 12.6 physicians per 10,000 residents. The data from the Ministry of the Interior also presents that the aging index in Yunlin County is 141.87, ranking second in Taiwan. In other words, Yunlin County is a relatively aging county. Past studies have also showed that living area affects the health behaviors of the elderly [7]. Compared with the general public living in cities, those living in aging areas engage in unhealthy behaviors more frequently, and their level of control over social and family resources is also lower [8]. Therefore, investigations associated with the medical care behaviors of the general public in specific aging areas may generate important research results. According to the literature, residents living in areas of population aging most frequently experience one or more chronic diseases [9]. The statistical data from the Public Health Bureau, in Yunlin County notes among the major causes of death in the county that diabetes ranks 3rd, suggesting that diabetes is one of the leading chronic diseases.

Based on the above, this study chose Yunlin as the research case due to its unique regional differences. Compared with other counties/cities in Taiwan, Yunlin features both population aging and a significant gap in medical resources, resulting in unique research values of the medical-care seeking behaviors of its residents. Moreover, relevant studies have indicated that differences in gender, age, marital status, educational level, and income lead to different perceptions of consultation about professional medical knowledge and use of medical services and further affect the subsequent medical-care seeking behaviors [10-12]. In other words, these demographic variables all affect patients' medical-care behaviors. Therefore, it is necessary to conduct studies to investigate whether such differences among the general public lead to varying satisfaction with medical care services. The research conclusions herein are provided as improvement strategies for the existing healthcare service system. The research results may also help better understand patients' distribution status and medical-care seeking habits so as to further achieve the objective of improving patients' accurate medical-care seeking behaviors.

The purpose of this study is to conduct a demographic survey to explore the relationship between lifestyle and the distribution of patients with Type 2 diabetes, and to investigate patients' visiting behaviors according to their degree of satisfaction with hospital service. The National Taiwan University Hospital, Yunlin Branch, was taken as the research field to explore the distribution of the population variables of patients with Type 2 diabetes, and whether their degree of satisfaction has any influence on visiting behavior through questionnaire survey.

The specific objectives of this study are as follows:

1. To understand the actual feeling and satisfaction of diabetic patients regarding the environment of the medical field and the service of medical staff.

2. The results of this study can actually reflect the real feelings of patients. In addition to providing medical field care advice, the results can provide medical personnel with relevant reference basis for the demographic variable of patients.

Although the cases selected in this study have regional limitations, they are still related to relevant situations, thus, they can provide comparison in the future when faced with relevant fields 
and situations. Although the cases cannot directly predict solutions or guide actions, they can put forward relevant problems through comparative analysis to compare similarities and differences in different situations.

\section{Materials and Methods}

This study used purposive sampling to collect cases from internal medicine wards and the diabetes health education center of a regional teaching hospital. This study collected 223 valid questionnaires from the Type 2 diabetes patients in the National Taiwan University Hospital, Yunlin Branch. The research questionnaire includes two parts. Part one covers structural questions that collect the respondents' basic demographic data, with the aim to perform a subsequent analysis on whether differences in patients' demographic characteristics lead to varying satisfaction with healthcare services. This study also investigates whether the satisfaction experienced by patients after receiving healthcare services affects their subsequent medical-care seeking behaviors. Therefore, part two of this questionnaire helps examine the satisfaction experienced by patients after seeking treatments in hospital and receiving healthcare services, in order to understand whether the demographic variables of respondents affect their satisfaction with healthcare services.

The research period cover June to September in 2018. Basic demographic data and satisfaction survey of hospital services were collected through structured questionnaires.

According to the literature, the following factors must be taken into consideration in studies on patients' medical-case seeking behavior patterns:

(1) Care quality (medical technology quality and service quality) [13,14].

(2) Medical conveniences (distance, convenient transportation, acquaintance with hospital staff, etc.) $[15,16]$.

(3) Hospital conditions (hardware facilities, quality, skills, and reputation of the hospital) [17].

(4) Required medical expenses [18].

For the required medical expenses mentioned in Item 4 above in the past literature, in compliance with Articles 43 and 47 of the National Health Insurance Act in Taiwan, the insured must only co-pay for their personal medical expenses. Therefore, the required medical expenses of medical visits to general public hospitals by the general public in Taiwan are the same, and patients only have to co-pay the expenses of their outpatient visits and medications. Therefore, this study does not include the required medical expenses in the questionnaire items and instead focuses on the services provided by hospitals.

The medical services provided by the medical facilities include: the service attitude of doctors and medical teams (including the registration staff, volunteers, personnel to price prescriptions and deliver drugs, senior nurses, and health educators), waiting time of patients, hardware provided by medical facilities (e.g., public service facilities, facilities for people with disabilities, and parking facilities in hospitals ), and software (e.g., moving lines, indicators, health education publicity system, related service App, and online service system). The questionnaire design of this study takes medical service satisfaction as a framework. According to the original medical services provided in the research field, the evaluation of patients' satisfaction with medical services are divided into three major dimensions: structure, process, and results [19]. Structure refers to the services provided by the hospital, such as the hospital environment and public facilities; process refers to the services provided by medical personnel in the process, such as medical team, prescription pricing, drug collection, registration, and other services; the dimension of results: the understanding and satisfaction of the patients with the return visit mechanism via the questionnaire survey according to the behavior of patients with diabetes seeking medical treatment. The above three dimensions constitute the questionnaire of this study. The first part of the questionnaire is a basic background survey in demographic variables. A Likert five-point scale was adopted by the questionnaire to measure the interviewees in terms of the 
various measures of the medical treatment process, with Very Satisfied: 5 points; Satisfied: 4 points; No comment: 3 points; Dissatisfied: 2 points; Very dissatisfied: 1 point.

The conditions for acceptance into this study were: a patient who been confirmed by a doctor's diagnosis to be a Type 2 diabetes patient, who is literate, conscious, and can communicate with others; while the exclusion conditions are that the patient has a cognitive impairment, cannot communicate with language, is illiterate or has a mental illness and cannot fully answer the content of the questionnaire. All questionnaires were counted by the anonymous method, and 223 questionnaires were collected, all of which were valid questionnaires, for a valid recovery rate of $100 \%$.

The data analysis method used was the Statistical Product and Service Solutions (SPSS) version 20.0 software (IBM, Armonk, New York, NY, USA). The analysis methods were narrative statistical analysis and one-way analysis of variance.

Descriptive statistical analysis was used to describe the characteristics of the sample, as well as the average value, standard deviation, percentage, and frequency distribution of various variables. The main purpose is to present the attributes and distribution status of the research target object to show the general situation of the existing medical service users. One-way analysis of variance is suitable for testing the difference of measurement scores between more than three different independent groups. In this research questionnaire, demographic variables (age, gender, education level, monthly income, occupation) are included in the questionnaire items, and analysis of variance was used to test whether there are differences in the satisfaction of service attitude of the medical teams, including waiting time and hardware and software services, due to different demographic variables. The demographic variables in Part 1 of the questionnaire are shown in Table 1.

Table 1. Demographic variables.

\begin{tabular}{|c|c|}
\hline Background Variable & Variable Items \\
\hline Gender & Male, female \\
\hline Age & Under $20,20-30,30-50,50-60$, over 60 \\
\hline Educational level & $\begin{array}{l}\text { Below primary school (inclusive), above junior high school, senior high school } \\
\text { (vocational high school), junior college, university, graduate school (inclusive) } \\
\text { and above }\end{array}$ \\
\hline Occupation & $\begin{array}{l}\text { Students, soldiers, public servants and teachers, industrial manufacturing, } \\
\text { commercial services, agriculture, forestry, fishing, animal husbandry and mining, } \\
\text { freelance, and others }\end{array}$ \\
\hline Monthly disposable income & $\begin{array}{l}\text { NT } \$ 10,000 \text { or less, NT } \$ 10,001-30,000, \text { NT } \$ 30,001-50,000, \text { NT } \$ 50,001-100,000 \text {, } \\
\text { NT } \$ 100,001 \text { or more }\end{array}$ \\
\hline
\end{tabular}

The content of the satisfaction dimension in Part 2 of the questionnaire is shown in Table 2. Taking medical users as the starting point, this survey focused on satisfaction with the outpatient treatment process.

Table 2. Satisfaction dimension.

\begin{tabular}{ll}
\hline Dimension & Description of Content \\
\hline Hospital service quality & $\begin{array}{l}\text { Including satisfaction with the software and hardware, environmental facilities, } \\
\text { and transportation services provided by the hospital } \\
\text { Satisfaction of waiting time for registration, medical treatment, drug collection, } \\
\text { inspection, and use of hospital-provided medical system } \\
\text { Paiting time }\end{array}$ \\
$\begin{array}{l}\text { Patient's satisfaction with completing the complete treatment process from } \\
\text { registration } \\
\text { Satisfaction with the instructions for medication and the service provided by the } \\
\text { hospital } \\
\text { Patient's satisfaction with return visit date and knowledge description service } \\
\text { provided by the hospital }\end{array}$ \\
\hline
\end{tabular}




\section{Results}

The sample data of this study were analyzed and counted by the SPSS statistical software. The main statistical methods included descriptive statistics and one-way analysis of variance. The analysis process is as follows. Part one is narrative statistics.

\subsection{The First Part of the Questionnaire, Demographic Variables}

This study collected 223 valid questionnaires from the Type 2 diabetes patients in the National Taiwan University Hospital, Yunlin Branch. The demographic variables of the patients include gender, age, education level, occupation category, and monthly disposable income. Table 3 is the gender number of times allocation, Table 4 is the age number of times allocation, and Table 5 is the gender and age cross tabulation.

Table 3. Gender.

\begin{tabular}{ccccc}
\hline Valid & Number of Times Allocation & Percentage & Effective Percentage & Cumulative Percentage \\
\hline Female & 121 & 54.3 & 54.3 & 54.3 \\
Male & 102 & 45.7 & 45.7 & 100.0 \\
Total & 223 & 100.0 & 100.0 & \\
\hline
\end{tabular}

Table 4. Age.

\begin{tabular}{ccccc}
\hline Valid & Number of Times Allocation & Percentage & Effective Percentage & Cumulative Percentage \\
\hline 20-30 years old & 4 & 1.8 & 1.8 & 1.8 \\
30-50 years old & 32 & 14.3 & 14.3 & 16.1 \\
50-60 years old & 52 & 23.3 & 23.3 & 39.5 \\
Over 60 years old & 135 & 60.5 & 60.5 & 100.0 \\
Total & 223 & 100.0 & 100.0 & \\
\hline
\end{tabular}

Table 5. Gender and age cross list.

\begin{tabular}{|c|c|c|c|c|c|c|}
\hline \multicolumn{7}{|c|}{ Gender *Age Cross List } \\
\hline \multicolumn{2}{|c|}{ Count } & 20-30 Years Old & 30-50 Years Old & 50-60 Years Old & Over 60 Years Old & Total \\
\hline \multirow{2}{*}{ Gender } & Female & 2 & 16 & 28 & 75 & 121 \\
\hline & Male & 2 & 16 & 24 & 60 & 102 \\
\hline \multicolumn{2}{|c|}{ Total } & 4 & 32 & 52 & 135 & 223 \\
\hline
\end{tabular}

According to the statistical results of this research questionnaire, the proportion of male and female is $45.7 \%$ and $54.3 \%$, respectively, indicating that the majority of the research objects are women.

Regarding the age distribution of the subjects in this study, four people were between 20 to 30 years old $(1.8 \%)$, 32 people were aged $30-50(14.3 \%)$, 52 people were aged $50-60(23.3 \%)$, and 135 people were aged over 60 (60.5\%).

As shown in the cross analysis table, regardless of the gender of the interviewee, the population aged over 60 accounts for the majority.

The following Table 6 is the education level number of times allocation, and Table 7 is the gender and education level cross tabulation. 
Table 6. Educational level.

\begin{tabular}{ccccc}
\hline Valid & $\begin{array}{c}\text { Number of Times } \\
\text { Allocation }\end{array}$ & Percentage & $\begin{array}{c}\text { Effective } \\
\text { Percentage }\end{array}$ & $\begin{array}{c}\text { Cumulative } \\
\text { Percentage }\end{array}$ \\
\hline Below primary school (inclusive) & 129 & 57.8 & 57.8 & 57.8 \\
Junior high school & 21 & 9.4 & 9.4 & 67.3 \\
High school (vocational high school) & 38 & 17.0 & 17.0 & 84.3 \\
Junior college & 11 & 4.9 & 4.9 & 89.2 \\
University & 16 & 3.2 & 3.6 & 100.0 \\
Graduate school or above & 8 & 100.0 & 100.0 & \\
Total & 223 & &
\end{tabular}

Table 7. Gender and educational level cross list.

\begin{tabular}{|c|c|c|c|c|c|c|c|c|}
\hline \multicolumn{9}{|c|}{ Gender*(3) Educational Level Cross List } \\
\hline \multicolumn{2}{|c|}{ Count } & $\begin{array}{c}\text { Below Primary } \\
\text { School } \\
\text { (Inclusive) }\end{array}$ & $\begin{array}{c}\text { Junior High } \\
\text { School }\end{array}$ & $\begin{array}{l}\text { High School } \\
\text { (Vocational } \\
\text { High School) }\end{array}$ & $\begin{array}{l}\text { Junior } \\
\text { College }\end{array}$ & University & $\begin{array}{c}\text { Graduate } \\
\text { School or } \\
\text { Above }\end{array}$ & Total \\
\hline \multirow{2}{*}{ Gender } & Female & 74 & 14 & 16 & 6 & 9 & 2 & 121 \\
\hline & Male & 55 & 7 & 22 & 5 & 7 & 6 & 102 \\
\hline \multicolumn{2}{|c|}{ Total } & 129 & 21 & 38 & 11 & 16 & 8 & 223 \\
\hline
\end{tabular}

There are 129 subjects with an educational level below primary school (7.8\%), 21 subjects with junior high school-level edication (9.4\%), 38 subjects with a senior high school (vocational high school) level (17\%), 11 junior college education subjects (4.9\%), 16 subjects with a university degree $(7.2 \%)$, and eight subjects with graduate school education $(3.6 \%)$.

As shown in the cross analysis table, regardless of gender of the interviewee, the educational level distribution was mostly below primary school.

The following Table 8 is the occupation number of times allocation, and Table 9 is the gender and career cross tabulation.

Table 8. Occupation.

\begin{tabular}{ccccc}
\hline Valid & $\begin{array}{c}\text { Number of Times } \\
\text { Allocation }\end{array}$ & Percentage & Effective Percentage & Cumulative Percentage \\
\hline Student & 2 & 0.9 & 0.9 & 0.9 \\
Soldiers, public servants and teachers & 9 & 4.0 & 4.0 & 4.9 \\
Industrial manufacturing & 11 & 4.9 & 7.6 & 17.9 \\
Business services & 17 & 14.6 & 4.3 & 31.8 \\
Agriculture, forestry, fishing, animal & 32 & 4.5 & 63.7 & 36.3 \\
husbandry and mining & 10 & 63.7 & 100.0 \\
Freelance & 142 & 100.0 & 100.0 \\
Other (including retirees) & 223 & & \\
\hline
\end{tabular}

Table 9. Gender and Career Cross List.

\begin{tabular}{|c|c|c|c|c|c|c|c|c|c|}
\hline \multicolumn{10}{|c|}{ Gender * Career Cross List } \\
\hline \multicolumn{2}{|c|}{ Count } & Student & \multirow{2}{*}{$\begin{array}{c}\begin{array}{c}\text { Soldiers, } \\
\text { Public } \\
\text { Servants and } \\
\text { Teachers }\end{array} \\
7\end{array}$} & \multirow{2}{*}{$\begin{array}{c}\begin{array}{l}\text { Industrial } \\
\text { Manufacturing }\end{array} \\
3\end{array}$} & \multirow{2}{*}{$\begin{array}{c}\text { Business } \\
\text { Services } \\
11\end{array}$} & \multirow{2}{*}{$\begin{array}{c}\text { Agriculture, } \\
\text { Forestry, } \\
\text { Fishing, Animal } \\
\text { Husbandry and } \\
\text { Mining } \\
13\end{array}$} & \multirow{2}{*}{$\begin{array}{c}\text { Freelance } \\
5\end{array}$} & \multirow{2}{*}{$\begin{array}{c}\begin{array}{c}\text { Other } \\
\text { (Including } \\
\text { Retirees) }\end{array} \\
81\end{array}$} & \multirow{2}{*}{\begin{tabular}{|r|} 
Total \\
121
\end{tabular}} \\
\hline & Female & 1 & & & & & & & \\
\hline Gender & Male & 1 & 2 & 8 & 6 & 19 & 5 & 61 & 102 \\
\hline \multicolumn{2}{|c|}{ Total } & 2 & 9 & 11 & 17 & 32 & 10 & 142 & 223 \\
\hline
\end{tabular}

Regarding the occupation of the subjects of this study, there were two students $(0.9 \%)$, nine soldiers, public servants, and teachers (4\%), 11 in industrial manufacturing industries (4.9\%), 17 in 
business service industries (7.6\%), 32 in agriculture, forestry, fishery, animal husbandry, and mining industries (14.3\%), 10 freelancers (4.5\%), and 142 other (including retirees) (63.7).

As shown in the cross analysis table, regardless of gender of the interviewee, the occupation of the subjects of this study was mostly retired.

The following Table 10 is the monthly disposable income number of times allocation, and Table 11 is the gender and monthly disposable income cross tabulation.

Table 10. Monthly disposable income.

\begin{tabular}{ccccc}
\hline Valid & Number of Times Allocation & Percentage & Effective Percentage & Cumulative Percentage \\
\hline $\begin{array}{c}10,000 \text { (inclusive) } \\
\text { and below }\end{array}$ & 118 & 52.9 & 52.9 & 52.9 \\
$10,001-30,000$ & 50 & 22.4 & 22.4 & 75.3 \\
$30,001-50,000$ & 36 & 16.1 & 16.1 & 91.5 \\
$50,001-100,000$ & 13 & 5.8 & 5.8 & 97.3 \\
100,001 (inclusive) & 6 & 2.7 & 2.7 & 100.0 \\
and above & 223 & 100.0 & 100.0 & \\
Total & & & \\
\hline
\end{tabular}

Table 11. Gender and monthly disposable income cross list.

\begin{tabular}{|c|c|c|c|c|c|c|c|}
\hline \multicolumn{8}{|c|}{ Gender * Monthly Disposable Income Cross List } \\
\hline \multicolumn{2}{|c|}{ Count } & $\begin{array}{c}\text { NTD 10,000 } \\
\text { (Inclusive) and } \\
\text { Below } \\
\text { NTD 10,000 or Less }\end{array}$ & \multirow{2}{*}{$\begin{array}{l}\text { NTD 10,001 } \\
-30,000 \\
31\end{array}$} & \multirow{2}{*}{$\begin{array}{c}\text { NTD } \\
30,001-50,000 \\
14\end{array}$} & \multirow[t]{2}{*}{$\begin{array}{c}\text { NTD } \\
\mathbf{5 0 , 0 0 1 - 1 0 0 , 0 0 0} \\
6\end{array}$} & \multirow[t]{2}{*}{$\begin{array}{c}\text { NTD 100,001 } \\
\text { (Inclusive) and } \\
\text { AboveNTD 100,001 } \\
\text { or Above }\end{array}$} & \multirow{2}{*}{\begin{tabular}{|c} 
Total \\
121
\end{tabular}} \\
\hline & Female & 67 & & & & & \\
\hline Gender & Male & 51 & 19 & 22 & 7 & 3 & 102 \\
\hline \multicolumn{2}{|c|}{ Total } & & 50 & 36 & 13 & 6 & 223 \\
\hline
\end{tabular}

New Taiwan dollar (NTD) is the official currency units in Taiwan. Regarding the monthly disposable income of the subjects, 118 subjects had below NTD 10,000 (52.9\%), 50 has NTD 10,001-30,000 (22.4\%), 36 has NTD 30,001-50,000 (16.1\%), 13 has NTD 50,001-100,000 (5.8\%), and six had NTD 10,0001 or above (2.7\%).

As shown in the cross analysis table, regardless of gender, the monthly disposable income was mostly NTD 10,000 or less. According to the demographic variables, the sample statistics of patients with Type 2 diabetes show that females were more numerous than males, and the population over 60 years old was the majority. The distribution of educational level was mostly below primary school, and occupation is mainly other (including retirees). The monthly disposable income was mostly below NTD 10,000.

\subsection{The Second Part of the Questionnaire is the Satisfaction Survey}

The second part is the satisfaction survey. First, the questionnaire items are listed in the table. According to literature, the evaluation of medical service satisfaction can be divided into three major dimensions: structure, process, and results:

(1) Structure: the service provided by the hospital; this dimension was named the service satisfaction of the medical structure.

(2) Process: the service provided by medical personnel in the process; this dimension was named as medical process service satisfaction.

(3) Results: According to the patient's behavior of seeking medical treatment, the questionnaire was used to inquire about the status and satisfaction of the return visit and the follow-up medication mechanism; this dimension was named as the satisfaction of medical service results. 
According to the literature, all items of the questionnaire were integrated into the above three dimensions, and then, the scores of each dimension were averaged and integrated into a single variable for subsequent statistical analysis. The research dimension scale is shown as follow Tables 12-14:

Table 12. Scale of medical structure service dimension.

\begin{tabular}{cl}
\hline Question Number & Question Item \\
\hline A1 & The waiting room has moderate air conditioning (for cooling and heating) \\
A2 & Facilities in waiting room (TV, seats, light, etc.) \\
A3 & Explicit signs or billboards \\
A4 & Activities in waiting room (TV broadcast or health education information) \\
A5 & Cleaning of floor and toilet \\
A6 & Hospital shuttle service \\
A7 & Transportation convenience provided by hospital (parking lot, etc.) \\
A8 & Visible medical facilities (wheelchairs, etc.) provided by hospitals \\
A9 & Hospital online service system (online registration, telephone reservation system) \\
A10 & Hospital entity service system (prescription pricing and drug collection counter) \\
A11 & Hospital medical facilities are safe and reliable \\
\hline
\end{tabular}

Table 13. Scale of medical process service dimension.

\begin{tabular}{ll}
\hline Question Number & Question Item \\
\hline B1 & The length of waiting time for registration \\
B3 & The length of waiting time for seeing a doctor \\
The length of meeting a doctor & The length of time to wait for the same day's examination (blood drawing, x-ray, other \\
examinations) & The time to arrange examination or inspection at another time \\
B5 & Time to wait for results of inspection report on the same day \\
B6 & The length of time to wait for the price of the prescription \\
B7 & The length of time to wait for the drug collection \\
B8 & The length of time to wait for using the medical system (e.g., online appointment \\
B9 & registration and consultation status inquiry) \\
B10 & Health Insurance Card insertion registration sequence process \\
B11 & Counter staff's description of the visit process \\
B12 & Senior nurse's statement on post-treatment process \\
B13 & Medical service staff's explanation on doubts about illness \\
B14 & Interpretation of medication information by pharmacy staff \\
B15 & Physician's explanation of doubts about illness \\
B16 & Health educator' interpretation of health education information \\
B17 & The prescription pricing and registration process is clear \\
B18 &
\end{tabular}

Table 14. Satisfaction with medical service results.

\begin{tabular}{cl}
\hline Question Number & Question Item \\
\hline C1 & The hospital provides instructions on the medicine bag \\
C2 & Instructions for drug use by hospital pharmacy staff \\
C3 & Instructions from hospital pharmacy staff for prescription and drug collection \\
C4 & Physician's instructions for medication \\
C5 & Physician's instructions for prescription and drug collection \\
C6 & Senior nurse's instructions for medication \\
C7 & Senior nurse's instructions for prescription and drug collection \\
C8 & Health educator's instructions for medication \\
C9 & Hospital provides medication information instructions (App or on paper, etc.) \\
C10 & Instructions for mediation from pharmacists for drug collection in non-hospital pharmacy \\
C11 & Instructions for prescription and drug collection from pharmacists for drug collection in \\
C12 & non-hospital pharmacy \\
\end{tabular}


Table 14. Cont.

\begin{tabular}{ll}
\hline Question Number & Question Item \\
\hline C13 & I can get the date of appointment made by the doctor for return visit \\
C14 & I can get the time of return visit notified by the senior nurse \\
C15 & I can get the time of return visit notified by the health educator \\
C16 & I can get the time of return visit through the instructions attached to the medicine bag \\
C18 & I can get the time of return visit through the instructions of the hospital counter staff \\
C19 & I can get the time of return visit via being reminded by my relatives \\
C20 & I can control the time of return visit without being reminded \\
C21 & I can exchange relevant information through patient groups \\
\hline
\end{tabular}

\subsection{Differences in Satisfaction of Population Variables}

In this part, the average score of satisfaction of the three dimensions is calculated by using the demographic variables, respectively, to learn whether the scores of each dimension are high or low for different demographic variables. Table 15 shows the result of using gender to calculate the average score of satisfaction of the three dimensions.

Table 15. Gender.

\begin{tabular}{|c|c|c|c|c|}
\hline & Gender & $\begin{array}{l}\text { Satisfaction of Medical } \\
\text { Structure Service }\end{array}$ & $\begin{array}{c}\text { Satisfaction with } \\
\text { Medical Process Service }\end{array}$ & $\begin{array}{c}\text { Satisfaction with } \\
\text { Medical Results and } \\
\text { Services }\end{array}$ \\
\hline \multirow{3}{*}{ Female } & Average value & 3.7498 & 3.6405 & 3.6044 \\
\hline & $\mathrm{N}$ & 121 & 121 & 120 \\
\hline & Standard deviation & 0.29813 & 0.25144 & 0.21330 \\
\hline \multirow{3}{*}{ Male } & Average value & 3.7567 & 3.7157 & 3.5901 \\
\hline & $\mathrm{N}$ & 102 & 102 & 102 \\
\hline & Standard deviation & 0.21716 & 0.26026 & 0.20160 \\
\hline \multirow{3}{*}{ Total } & Average value & 3.7530 & 3.6749 & 3.5978 \\
\hline & $\mathrm{N}$ & 223 & 223 & 222 \\
\hline & Standard deviation & 0.26365 & 0.25768 & 0.20766 \\
\hline
\end{tabular}

According to the table, the scores of both genders in the dimensions of medical structure, process, and results of the questionnaire are even. The highest score is women's satisfaction with medical structure service, with an average score of 3.74, and the lowest is their satisfaction with medical result service, with a score of 3.6. The highest score for men is the same as that for medical structure service, with an average score of 3.75 , and the lowest is the same as that for medical result service, with a score of 3.59.

The following Table 16 shows the result of using age to calculate the average score of satisfaction of the three dimensions. 
Table 16. Age.

\begin{tabular}{|c|c|c|c|c|}
\hline \multicolumn{2}{|c|}{ Age } & \multirow{2}{*}{$\begin{array}{c}\begin{array}{c}\text { Satisfaction of } \\
\text { Medical Structure } \\
\text { Service }\end{array} \\
3.7955\end{array}$} & \multirow{2}{*}{$\begin{array}{c}\begin{array}{c}\text { Satisfaction with } \\
\text { Medical Process } \\
\text { Service }\end{array} \\
3.9167\end{array}$} & \multirow{2}{*}{$\begin{array}{c}\begin{array}{c}\text { Satisfaction with } \\
\text { Medical Results } \\
\text { and Services }\end{array} \\
3.7857\end{array}$} \\
\hline & Average value & & & \\
\hline 20-30 years old & $\mathrm{N}$ & 4 & 4 & 4 \\
\hline & Standard deviation & 0.13636 & 0.22453 & 0.16265 \\
\hline \multirow{3}{*}{$30-50$ years old } & Average value & 3.7386 & 3.7014 & 3.5883 \\
\hline & $\mathrm{N}$ & 32 & 32 & 31 \\
\hline & Standard deviation & 0.19006 & 0.21895 & 0.23700 \\
\hline \multirow{3}{*}{ 50-60 years old } & Average value & 3.7185 & 3.6346 & 3.5614 \\
\hline & $\mathrm{N}$ & 52 & 52 & 52 \\
\hline & Standard deviation & 0.22141 & 0.24683 & 0.21655 \\
\hline \multirow{3}{*}{ Over 60 years old } & Average value & 3.7684 & 3.6770 & 3.6085 \\
\hline & $\mathrm{N}$ & 135 & 135 & 135 \\
\hline & Standard deviation & 0.29483 & 0.26843 & 0.19596 \\
\hline \multirow{3}{*}{ Total } & Average value & 3.7530 & 3.6749 & 3.5978 \\
\hline & $\mathrm{N}$ & 223 & 223 & 222 \\
\hline & Standard deviation & 0.26365 & 0.25768 & 0.20766 \\
\hline
\end{tabular}

The scores of the subjects of different ages in all aspects of the questionnaire are even, with the highest score of medical process service satisfaction being 3.79, ranging from 20 to 30 years old, and the lowest score being 3.71, ranging from 50 to 60 years old. The highest score for the satisfaction degree of medical process service is 3.91, which falls in the range of 20-30 years old, and the lowest is 3.63, which falls in the range of 50-60 years old. The highest score for the satisfaction degree of medical service results is 3.78 , falling in the $20-30$ age range, and the lowest score is 3.56 , falling in the 50-60 age range.

The scores of the various educational levels in all aspects of the questionnaire are even, with the highest score of 3.81 for medical process service satisfaction, falling within the junior high school range, and the lowest score of 3.63, falling within the university range. The highest score of the satisfaction degree of medical process service is 3.76 , which falls in the university section, and the lowest is 3.63 , which falls in the junior college section. The highest score for the satisfaction degree of medical service results is 3.67 , falling in the university range, and the lowest is 3.57 , falling in the high school (vocational high school) range.

The following Table 17 shows the result of using education level to calculate the average score of satisfaction of the three dimensions.

The following Table 18 shows the result of using occupation to calculate the average score of satisfaction of the three dimensions.

The scores of the different occupations in all aspects of the questionnaire are even, with the highest score of 3.77 for medical process service satisfaction, falling within the range of agriculture, forestry, fishing, animal husbandry, and mining industries, and the lowest score of 3.45, falling within the section of students. The highest satisfaction degree of medical process service is 3.81 , which falls in the section of soldiers, public servants, and teachers, and the lowest is 3.47, which falls in the section of students. The highest score for the satisfaction degree of medical service results is 3.77 , falling within the range of soldiers, public servants, and teachers, and the lowest is 3.52 , falling within the industrial manufacturing range.

The following Table 19 shows the result of using monthly disposable income to calculate the average score of satisfaction of the three dimensions. 
Table 17. Educational level.

\begin{tabular}{|c|c|c|c|c|}
\hline \multicolumn{2}{|c|}{ Educational Level } & \multirow{2}{*}{$\begin{array}{c}\begin{array}{c}\text { Satisfaction of } \\
\text { Medical Structure } \\
\text { Service }\end{array} \\
3.7541\end{array}$} & \multirow{2}{*}{$\begin{array}{c}\text { Satisfaction with } \\
\text { Medical Process } \\
\text { Service }\end{array}$} & \multirow{2}{*}{$\begin{array}{c}\begin{array}{c}\text { Satisfaction with } \\
\text { Medical Results } \\
\text { and Services }\end{array} \\
3.5919\end{array}$} \\
\hline & Average value & & & \\
\hline Below primary school & $\mathrm{N}$ & 129 & 129 & 128 \\
\hline & Standard deviation & 0.24541 & 0.26837 & 0.18560 \\
\hline \multirow{3}{*}{ Junior high school } & Average value & 3.8139 & 3.6720 & 3.5918 \\
\hline & $\mathrm{N}$ & 21 & 21 & 21 \\
\hline & Standard deviation & 0.14792 & 0.22216 & 0.09709 \\
\hline \multirow{3}{*}{$\begin{array}{l}\text { High school (vocational high } \\
\text { school) }\end{array}$} & Average value & 3.7608 & 3.6769 & 3.5752 \\
\hline & $\mathrm{N}$ & 38 & 38 & 38 \\
\hline & Standard deviation & 0.26434 & 0.20211 & 0.22995 \\
\hline \multirow{3}{*}{ Junior college } & Average value & 3.7686 & 3.6364 & 3.6190 \\
\hline & $\mathrm{N}$ & 11 & 11 & 11 \\
\hline & Standard deviation & 0.13088 & 0.13232 & 0.10859 \\
\hline \multirow{3}{*}{ University } & Average value & 3.6364 & 3.7604 & 3.6726 \\
\hline & $\mathrm{N}$ & 16 & 16 & 16 \\
\hline & Standard deviation & 0.50562 & 0.36273 & 0.42623 \\
\hline \multirow{3}{*}{ Graduate school or above } & Average value & 3.7500 & 3.6667 & 3.6369 \\
\hline & $\mathrm{N}$ & 8 & 8 & 8 \\
\hline & Standard deviation & 0.23681 & 0.32394 & 0.07171 \\
\hline \multirow{3}{*}{ Total } & Average value & 3.7530 & 3.6749 & 3.5978 \\
\hline & $\mathrm{N}$ & 223 & 223 & 222 \\
\hline & Standard deviation & 0.26365 & 0.25768 & 0.20766 \\
\hline
\end{tabular}

Table 18. Occupation.

\begin{tabular}{|c|c|c|c|c|}
\hline \multicolumn{2}{|c|}{ Occupation } & \multirow{2}{*}{$\begin{array}{c}\begin{array}{c}\text { Satisfaction of } \\
\text { Medical Structure } \\
\text { Service }\end{array} \\
3.4545\end{array}$} & \multirow{2}{*}{ 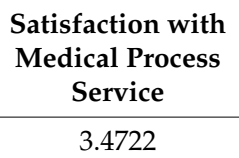 } & \multirow{2}{*}{$\begin{array}{c}\begin{array}{c}\text { Satisfaction with } \\
\text { Medical Results } \\
\text { and Services }\end{array} \\
3.7143\end{array}$} \\
\hline & Average value & & & \\
\hline Students & $\mathrm{N}$ & 2 & 2 & 1 \\
\hline & Standard deviation & 0.64282 & 0.66782 & \\
\hline \multirow{3}{*}{$\begin{array}{l}\text { Soldiers, public servants } \\
\text { and teachers }\end{array}$} & Average value & 3.6465 & 3.8148 & 3.7725 \\
\hline & $\mathrm{N}$ & 9 & 9 & 9 \\
\hline & Standard deviation & 0.63220 & 0.41295 & 0.48374 \\
\hline \multirow{3}{*}{$\begin{array}{c}\text { Industrial } \\
\text { manufacturing }\end{array}$} & Average value & 3.7438 & 3.7576 & 3.5281 \\
\hline & $\mathrm{N}$ & 11 & 11 & 11 \\
\hline & Standard deviation & 0.16673 & 0.35335 & 0.38241 \\
\hline \multirow{3}{*}{ Business services } & Average value & 3.7647 & 3.6405 & 3.5742 \\
\hline & $\mathrm{N}$ & 17 & 17 & 17 \\
\hline & Standard deviation & 0.21575 & 0.22491 & 0.18013 \\
\hline \multirow{3}{*}{$\begin{array}{l}\text { Agriculture, forestry, } \\
\text { fishing, animal } \\
\text { husbandry and mining }\end{array}$} & Average value & 3.7756 & 3.6597 & 3.5759 \\
\hline & $\mathrm{N}$ & 32 & 32 & 32 \\
\hline & Standard deviation & 0.21536 & 0.20142 & 0.11240 \\
\hline \multirow{3}{*}{ Freelance } & Average value & 3.6545 & 3.6000 & 3.6762 \\
\hline & $\mathrm{N}$ & 10 & 10 & 10 \\
\hline & Standard deviation & 0.29629 & 0.24117 & 0.07027 \\
\hline \multirow{3}{*}{ Other (including retirees) } & Average value & 3.7650 & 3.6753 & 3.5936 \\
\hline & $\mathrm{N}$ & 142 & 142 & 142 \\
\hline & Standard deviation & 0.24046 & 0.24804 & 0.18470 \\
\hline \multirow{3}{*}{ Total } & Average value & 3.7530 & 3.6749 & 3.5978 \\
\hline & $\mathrm{N}$ & 223 & 223 & 222 \\
\hline & Standard deviation & 0.26365 & 0.25768 & 0.20766 \\
\hline
\end{tabular}


Table 19. Monthly Disposable Income.

\begin{tabular}{ccccc}
\hline \multirow{2}{*}{ Monthly Disposable Income } & Satisfaction of & $\begin{array}{c}\text { Medical Structure } \\
\text { Service }\end{array}$ & $\begin{array}{c}\text { Satisfaction with } \\
\text { Medical Process } \\
\text { Service }\end{array}$ & $\begin{array}{c}\text { Satisfaction with } \\
\text { Medical Results } \\
\text { and Services }\end{array}$ \\
\hline \multirow{3}{*}{10,000 or below } & Average value & 3.7581 & 3.6737 & 3.5950 \\
& N & 118 & 118 & 117 \\
& Standard deviation & 0.23956 & 0.26425 & 0.18193 \\
\hline \multirow{2}{*}{ NTD 10,001-30,000 } & Average value & 3.7545 & 3.6556 & 3.5895 \\
& N & 50 & 50 & 50 \\
& Standard deviation & 0.17925 & 0.22023 & 0.13568 \\
\hline \multirow{2}{*}{ NTD 30,001-50,000 } & Average value & 3.7702 & 3.6944 & 3.5714 \\
& N & 36 & 36 & 36 \\
& Standard deviation & 0.20326 & 0.22003 & 0.24467 \\
\hline \multirow{2}{*}{ NTD 50,001-100,000 } & Average value & 3.6224 & 3.6239 & 3.6740 \\
& N & 13 & 13 & 13 \\
& Standard deviation & 0.55403 & 0.29931 & 0.27067 \\
\hline \multirow{2}{*}{ NTD 100,001 or above } & Average value & 3.8182 & 3.8519 & 3.7143 \\
& N & 6 & 6 & 6 \\
& Standard deviation & 0.59196 & 0.48390 & 0.57063 \\
\hline & Average value & 3.7530 & 3.6749 & 3.5978 \\
& N & 223 & 223 & 222 \\
& Standard deviation & 0.26365 & 0.25768 & 0.20766 \\
\hline
\end{tabular}

The scores of the different occupational categories are even in all aspects of the questionnaire, with the highest score of 3.81 for medical process service satisfaction, falling within the range of monthly disposable income of NTD 100,001 or above, and the lowest score of 3.62, falling within the range of monthly disposable income of 50,001-100,000. The highest score for the satisfaction degree of medical process service is 3.85, which falls in the range of monthly disposable income of NTD 100,001 or above, and the lowest is 3.62 and falls in the range of monthly disposable income of NTD 50,001-100,000. The highest score for the satisfaction degree of medical service results is 3.71 , falling within the range of monthly disposable income of NTD 100,001 or above, and the lowest is 3.57, falling within the range of monthly disposable income of NTD 30,001-50,000. All the above currency units were New Taiwan Dollars.

\subsection{One-way Analysis of Variance}

In this part, according to the questionnaire dimension scale, the data were used to test the differences in the structure, process, and results of the dimension content through statistical methods aiming at the demographic variables of the research object as the variance. The purpose is to explore whether there are significant differences in the perception of medical service satisfaction among groups of different attributes. Table 20 shows the narrative statistics analysis of gender and scale dimension variables, and Table 21 is the result of analysis of variance. 
Table 20. Analysis of gender and scale dimension variables.

\begin{tabular}{|c|c|c|c|c|c|c|c|c|c|}
\hline \multicolumn{10}{|c|}{ Narrative Statistics } \\
\hline \multirow{2}{*}{\multicolumn{2}{|c|}{ Questionnaire Dimension Scale }} & \multirow[t]{2}{*}{$\mathbf{N}$} & \multirow[t]{2}{*}{$\begin{array}{l}\text { Average } \\
\text { Value }\end{array}$} & \multirow[t]{2}{*}{$\begin{array}{l}\text { Standard } \\
\text { Deviation }\end{array}$} & \multirow[t]{2}{*}{$\begin{array}{l}\text { Standard } \\
\text { Error }\end{array}$} & \multicolumn{2}{|c|}{$\begin{array}{l}95 \% \text { Confidence } \\
\text { Interval of } \\
\text { Average Value }\end{array}$} & \multirow[t]{2}{*}{$\begin{array}{l}\text { Minimum } \\
\text { Value }\end{array}$} & \multirow[t]{2}{*}{$\begin{array}{l}\text { Maximum } \\
\text { Value }\end{array}$} \\
\hline & & & & & & $\begin{array}{c}\text { Lower } \\
\text { Limit }\end{array}$ & $\begin{array}{l}\text { Upper } \\
\text { Limit }\end{array}$ & & \\
\hline \multirow{3}{*}{$\begin{array}{l}\text { Satisfaction of medical } \\
\text { structure service }\end{array}$} & Female & 121 & 3.7498 & 0.29813 & 0.02710 & 3.6962 & 3.8035 & 2.55 & 5.00 \\
\hline & Male & 102 & 3.7567 & 0.21716 & 0.02150 & 3.7140 & 3.7993 & 3.00 & 4.00 \\
\hline & Total & 223 & 3.7530 & 0.26365 & 0.01766 & 3.7182 & 3.7877 & 2.55 & 5.00 \\
\hline \multirow{3}{*}{$\begin{array}{l}\text { Satisfaction with } \\
\text { medical process } \\
\text { service }\end{array}$} & Female & 121 & 3.6405 & 0.25144 & 0.02286 & 3.5952 & 3.6858 & 3.00 & 4.78 \\
\hline & Male & 102 & 3.7157 & 0.26026 & 0.02577 & 3.6646 & 3.7668 & 3.00 & 4.28 \\
\hline & Total & 223 & 3.6749 & 0.25768 & 0.01726 & 3.6409 & 3.7089 & 3.00 & 4.78 \\
\hline \multirow{3}{*}{$\begin{array}{l}\text { Satisfaction with } \\
\text { medical results and } \\
\text { services }\end{array}$} & Female & 120 & 3.6044 & 0.21330 & 0.01947 & 3.5658 & 3.6429 & 2.95 & 4.71 \\
\hline & Male & 102 & 3.5901 & 0.20160 & 0.01996 & 3.5505 & 3.6297 & 2.48 & 4.00 \\
\hline & Total & 222 & 3.5978 & 0.20766 & 0.01394 & 3.5703 & 3.6253 & 2.48 & 4.71 \\
\hline
\end{tabular}

Table 21. Variance analysis.

\begin{tabular}{|c|c|c|c|c|c|c|}
\hline \multicolumn{7}{|c|}{ Variance Analysis } \\
\hline \multicolumn{2}{|c|}{ Questionnaire Dimension Scale } & Sum of Squares & Variance & Mean Square & $\mathbf{F}$ & Significance \\
\hline \multirow{3}{*}{$\begin{array}{l}\text { Satisfaction of medical } \\
\text { structure service }\end{array}$} & Between groups & 0.003 & 1 & 0.003 & 0.037 & 0.847 \\
\hline & Within a group & 15.429 & 221 & 0.070 & & \\
\hline & Total & 15.431 & 222 & & & \\
\hline \multirow{3}{*}{$\begin{array}{l}\text { Satisfaction with medical } \\
\text { process service }\end{array}$} & Between groups & 0.313 & 1 & 0.313 & 4.793 & 0.030 \\
\hline & Within a group & 14.428 & 221 & 0.065 & & \\
\hline & Total & 14.741 & 222 & & & \\
\hline \multirow{3}{*}{$\begin{array}{l}\text { Satisfaction with medical } \\
\text { results and services }\end{array}$} & Between groups & 0.011 & 1 & 0.011 & 0.259 & 0.611 \\
\hline & Within a group & 9.519 & 220 & 0.043 & & \\
\hline & Total & 9.530 & 221 & & & \\
\hline
\end{tabular}

From the table, it can be seen that there are significant differences between males and females in the degree of satisfaction with medical process service, where the average score of males is 3.71 and that of females is 3.64. Male patients are more satisfied with the service process provided by medical institutions, as compared with female patients.

The following Table 22 is analysis of variance between age and scale dimension.

Table 22. Analysis of age and scale dimension variables.

\begin{tabular}{|c|c|c|c|c|c|c|}
\hline \multicolumn{7}{|c|}{ Variance Analysis } \\
\hline \multicolumn{2}{|c|}{ Questionnaire Dimension Scale } & Sum of Squares & Variance & Mean Square & $\mathbf{F}$ & Significance \\
\hline \multirow{3}{*}{$\begin{array}{l}\text { Satisfaction of medical } \\
\text { structure service }\end{array}$} & Between groups & 0.107 & 3 & 0.036 & 0.512 & 0.675 \\
\hline & Within a group & 15.324 & 219 & 0.070 & & \\
\hline & Total & 15.431 & 222 & & & \\
\hline \multirow{3}{*}{$\begin{array}{l}\text { Satisfaction with medical } \\
\text { process service }\end{array}$} & Between groups & 0.341 & 3 & 0.114 & 1.730 & 0.162 \\
\hline & Within a group & 14.400 & 219 & 0.066 & & \\
\hline & Total & 14.741 & 222 & & & \\
\hline \multirow{3}{*}{$\begin{array}{l}\text { Satisfaction with medical } \\
\text { results and services }\end{array}$} & Between groups & 0.228 & 3 & 0.076 & 1.785 & 0.151 \\
\hline & Within a group & 9.302 & 218 & 0.043 & & \\
\hline & Total & 9.530 & 221 & & & \\
\hline
\end{tabular}

It can be seen from the table that there is no significant difference in the satisfaction scores of patients for all dimensions, regardless of whether they are under 20 years old, 20-30 years old, 30-50 years old, 50-60 years old, or over 60 years old.

The following Table 23 is analysis of variance between educational level and scale dimension. 
Table 23. Analysis of educational level and scale dimension variables.

\begin{tabular}{|c|c|c|c|c|c|c|}
\hline \multicolumn{7}{|c|}{ Variance Analysis } \\
\hline \multicolumn{2}{|c|}{ Questionnaire Dimension Scale } & Sum of Squares & Variance & Mean Square & F & Significance \\
\hline \multirow{3}{*}{$\begin{array}{l}\text { Satisfaction of medical } \\
\text { structure service }\end{array}$} & Between groups & 0.301 & 5 & 0.060 & 0.862 & 0.507 \\
\hline & Within a group & 15.131 & 217 & 0.070 & & \\
\hline & Total & 15.431 & 222 & & & \\
\hline \multirow{3}{*}{$\begin{array}{l}\text { Satisfaction with medical } \\
\text { process service }\end{array}$} & Between groups & 0.140 & 5 & 0.028 & 0.417 & 0.836 \\
\hline & Within a group & 14.601 & 217 & 0.067 & & \\
\hline & Total & 14.741 & 222 & & & \\
\hline \multirow{3}{*}{$\begin{array}{l}\text { Satisfaction with medical } \\
\text { results and services }\end{array}$} & Between groups & 0.131 & 5 & 0.026 & 0.604 & 0.697 \\
\hline & Within a group & 9.399 & 216 & 0.044 & & \\
\hline & Total & 9.530 & 221 & & & \\
\hline
\end{tabular}

According to the statistical results, there is no significant difference in satisfaction scores for all service components in the hospital, regardless of whether the educational level was primary school or below, junior high school, senior high school (vocational high school), junior college, university, and graduate school or above.

The following Table 24 is analysis of variance between occupational category and scale dimension.

Table 24. Analysis of occupational category and scale dimension variables.

\begin{tabular}{|c|c|c|c|c|c|c|}
\hline \multicolumn{7}{|c|}{ Variance Analysis } \\
\hline \multicolumn{2}{|c|}{ Questionnaire Dimension Scale } & Sum of Squares & Variance & Mean Square & $\mathbf{F}$ & Significance \\
\hline \multirow{3}{*}{$\begin{array}{l}\text { Satisfaction of medical } \\
\text { structure service }\end{array}$} & Between groups & 0.417 & 6 & 0.070 & 1.001 & 0.426 \\
\hline & Within a group & 15.014 & 216 & 0.070 & & \\
\hline & Total & 15.431 & 222 & & & \\
\hline \multirow{3}{*}{$\begin{array}{l}\text { Satisfaction with medical } \\
\text { process service }\end{array}$} & Between groups & 0.417 & 6 & 0.070 & 1.048 & 0.395 \\
\hline & Within a group & 14.324 & 216 & 0.066 & & \\
\hline & Total & 14.741 & 222 & & & \\
\hline \multirow{3}{*}{$\begin{array}{l}\text { Satisfaction with medical } \\
\text { results and services }\end{array}$} & Between groups & 0.430 & 6 & 0.072 & 1.695 & 0.124 \\
\hline & Within a group & 9.100 & 215 & 0.042 & & \\
\hline & Total & 9.530 & 221 & & & \\
\hline
\end{tabular}

From the table, it can be seen that the patients' satisfaction scores for all service components in the hospital are not significantly different, regardless of their occupation: students, soldiers, public servants and teachers, industrial manufacturing, business service industry, agriculture, forestry, fishing, animal husbandry, mining, freelance, or others.

The following Table 25 is analysis of variance between monthly disposable income and scale dimension.

Table 25. Analysis of Monthly Disposable Income and Scale Dimension Variables.

\begin{tabular}{|c|c|c|c|c|c|c|}
\hline \multicolumn{7}{|c|}{ Variance Analysis } \\
\hline \multicolumn{2}{|c|}{ Questionnaire Dimension Scale } & Sum of Squares & Variance & Mean Square & $\mathbf{F}$ & Significance \\
\hline \multirow{3}{*}{$\begin{array}{l}\text { Satisfaction of medical } \\
\text { structure service }\end{array}$} & Between groups & 0.261 & 4 & 0.065 & 0.938 & 0.443 \\
\hline & Within a group & 15.170 & 218 & 0.070 & & \\
\hline & Total & 15.431 & 222 & & & \\
\hline \multirow{3}{*}{$\begin{array}{l}\text { Satisfaction with medical } \\
\text { process service }\end{array}$} & Between groups & 0.254 & 4 & 0.064 & 0.957 & 0.432 \\
\hline & Within a group & 14.487 & 218 & 0.066 & & \\
\hline & Total & 14.741 & 222 & & & \\
\hline \multirow{3}{*}{$\begin{array}{l}\text { Satisfaction with medical } \\
\text { results and services }\end{array}$} & Between groups & 0.186 & 4 & 0.047 & 1.081 & 0.367 \\
\hline & Within a group & 9.344 & 217 & 0.043 & & \\
\hline & Total & 9.530 & 221 & & & \\
\hline
\end{tabular}


From the table, it can be seen that patients' satisfaction scores for all service components in the hospital have no significant difference, regardless of whether their disposable income is below 10,000, NTD 10,001-30,000, NTD 30,001-50,000, NTD 50,001-100,000, and above NTD 10,000.

\section{Discussion}

In this study, 223 patients from the National Taiwan University Hospital, Yunlin Branch, were selected as the research subjects, all of whom were diagnosed as having Type 2 diabetes by the attending doctors. The results show that there were no significant differences in the satisfaction scores of demographic variables, such as age, education level, occupation category, and monthly disposable income for the services provided in the medical facilities in terms of structure (hardware and environment), process, and results. However, there was one variable, gender, which showed a significant difference in satisfaction with the medical process service. Statistical results show that male patients had higher scores than female patients in the service process provided by medical institutions, that is, the service provided in the process by medical personnel (including the overall process of medical team inquiry, prescription pricing, drug collection, registration, and drug description). On the whole, the statistical data of this study shows that patients' satisfaction with the hardware facilities in the medical facilities was high. Although there were differences in scores regarding process, the overall average score was still above 3.5 points. In the dimension of results, there was no group difference. On the whole, the statistical data of this study found that the patients were older, most of whom were over 60 years old, with lower education level, most of whom had retired, and earning less than NTD 10,000, and the average score of each dimension was above 3.5 points. It was obvious that they had a certain positive feeling of satisfaction with medical services. Although this study adopted the purposive sampling method, and was limited by the lack of research manpower and time, face-to-face and anonymous single inquiries were directly adopted as the investigation method, in order that the interviewees could truly reflect their feelings, and the statistical results are still of reference value. This study can be used as a reference for subsequent medical service personnel, who may use it as a basis and guideline for service improvement.

\section{Conclusions}

This study explored whether groups of different demographic variables have different feelings and degrees of satisfaction with the services provided by medical facilities through a satisfaction survey. Although this study has regional limitations, and it is not possible to extend the results to all fields, the place where the study was conducted was a regional medical institution. Hence, the relevant results can still be used as control and reference for similar situations in the future. Moreover, different parts can be pointed out in different situations through comparisons and proposal of related problems. In addition, this study did not intend to survey the satisfaction of all the people with medical services, but focused on patients with Type 2 diabetes in our hospital, which aimed to break through the general questionnaire survey method, while neglecting the in-depth exploration and research of specific groups. Although the large number of samples are representative, the questionnaire, which was designed for the actual situation faced by specific objects, can still provide reliable results. The nature of this study is a pilot study. In this study, patients' understanding of service quality is classified into the "medical result service" part of the scale dimension. It is suggested that follow-up studies can track the status of controlling patients' glycated hemoglobin to determine whether patients' medical cognition and service satisfaction have influence on their own disease control degree, and then, to speculate whether the level of patients' service satisfaction will interfere with patients' behavior and decisions in selecting medical institutions, thus, affecting disease control.

This study takes the National Taiwan University Hospital, Yunlin Branch as its research case sample. Located in Douliu City, Yunlin, Taiwan. This hospital offers a wide range of medical services. We find that patients in Yunlin exhibit differences from those patients in other counties/cities in Taiwan. The questionnaire scores also show no significant difference in satisfaction with transportation services 
offered by the healthcare institution. For the demographic characteristics of the patients, $60.5 \%$ are the elderly, and the educational level of $57.8 \%$ of all patients is elementary school (and under). The research results illustrate no significant difference in satisfaction with the services provided by the healthcare institution, including structures (hardware and environment), processes, and outcomes. We can see that patients' satisfaction with the services provided by the hospital is almost the same, despite the differences in their demographic variables. However, the patients in this study are mainly the elderly with a very low educational level. For them, there is no significant difference in their satisfaction with the medical services they received.

The data from the Department of Statistics, Ministry of Health and Welfare in Taiwan present that a mean of 44.38 patients per 100,000 with diabetes in every county/city in Taiwan passed away. For Yunlin County, this number went up to 70 patients who passed away, ranking 2nd nationwide and far exceeding the mean. Diabetes is a chronic disease, and many past clinical experiments and trials have proved in addition to receiving medical diagnosis and medication control that patients also have to receive long-term care and methods of control in order to effectively help relieve their disease condition. According to the statistical results herein, future studies are advised to use other qualitative research methods, such as in-depth interviews and field research, to investigate whether other medication, care, and life patterns of elderly patients with diabetes whose educational level is lower are affected by other factors. Such factors may result in a higher mortality rate of patients with diabetes in Yunlin compared with those in other counties/cities after they receive medical diagnosis, despite their high satisfaction with services.

Author Contributions: Investigation, Y.-L.L.; Methodology, Y.-L.L.; Project administration, J.-c.T. and F.-J.N.; Supervision, J.-c.T. and F.-J.N.; Writing - original draft, Y.-L.L.; Writing - review \& editing, J.-c.T.

Funding: This research was funded National Taiwan University Hospital Yun-Lin Branch, grant number: NTUHYL107.C027.

Acknowledgments: This research was supported by National Taiwan University Hospital Yunlin Branch funded project. (Number: NTUHYL107.C027).

Conflicts of Interest: The authors declare no conflict of interest.

\section{References}

1. World Health Organization. Global Report on Diabetes 2016, pp. 35-42. Available online: https://goo.gl/ g5KCtx (accessed on 22 December 2018).

2. Wu, L.-Y. Satisfaction of Care and Correlation Factor Discussion in Public Health Center with Type 2 diabetes Mellitus: Take Sikou Township as an Example. Master's Thesis, Nanhua University, Chiayi, Taiwan, 2012. Available online: https://goo.gl/QtsHDj (accessed on 9 October 2018).

3. Huang, M.; Lin, L.; Hung, C. Correlates of Patients' Self-care Behaviors with Type 2 diabetes Mellitus. J. Long-Term Care 2010, 12. [CrossRef]

4. Tsai, S. The Study and Design Base on User Experience-A Case of Diabetes Diet Diary Application. Master's Thesis, National Taiwan University of Science and Technology, Taipei, Taiwan, 2013. Available online: https:/ / hdl.handle.net/11296/n26sqm (accessed on 25 October 2018).

5. Liu, M.; Tai, Y.; Hung, W.; Hsieh, M.; Wang, R. Relationships between Emotional Distress, Empowerment Perception and Self-Care Behavior and Quality of Life in Patients with Type 2 diabetes. J. Nurs. 2010, 57, 49-60. [CrossRef]

6. Lee, Y.; Huang, Y.; Huang, K.; Huang, K.-H.; Yeh, L.-L.; Chen, P.-C. The Review and Prospect of the National Health Insurance Payment System Reform. Formos. J. Med. 2014, 18. [CrossRef]

7. Lin, Y.C.; Yen, L.L.; Chen, S.Y.; Kao, M.D.; Tzeng, M.S.; Huang, P.C.; Pan, W.H. Prevalence of overweight and obesity and its associated factors: Findings from National Nutrition and Health Survey in Taiwan, 1993-1996. Prev. Med. 2003, 37, 233-241. [CrossRef]

8. Leung, K.; Hsu, S.; Chen, C.Y.; Chen, C. Health Status of Elders in Urban and Rural Communities. Formos. J. Med. 2002, 6, 523-534. [CrossRef] 
9. Chao, A.; Gau, M.; Lin, S. The Relationships between Health Status and Quality of Life among Rural Community Elderly Dwellers. J. Long-Term Care 2004, 8, 41-55.

10. Twigg, J.; Atkin, K. Carers Perceived: Policy and Practice in Informal Care; Open University Press: Buckingham, UK, 1994.

11. Beardon, P.H.G.; McGilchrist, M.M.; McKendrick, A.D.; McDevitt, D.G.; Macdonald, T.M. Primary non-compliance with prescribed medication in primary care. BMJ 1993, 307, 846-848. [CrossRef] [PubMed]

12. Mitchell, J.R.; Schwartz, C.J. Relationship between arterial disease at different sites. Br. Med. J. 1962, 1, 1293-1301. [CrossRef] [PubMed]

13. Inguanzo, J.M.; Harju, M. What Makes Consumers Select a Hospital. Hospitals 1985, 59, 90-94. [PubMed]

14. Lane, P.M.; Lindquist, J.D. Hospital choice: A summary of the key empirical and hypothetical findings of the 1980s. J Health Care Mark. 1988, 8, 5-20. [PubMed]

15. Boscarino, J.; Steiber, S.R. Hospital shopping and consumer choice. J. Health Care Mark. 1982, 2, $15-23$. [PubMed]

16. Javalgi, R.G.; Rao, S.R.; Thomas, E.G. Choosing a hospital: Analysis of consumer tradeoffs. J. Health Care Mark. 1991, 11, 12-22. [PubMed]

17. Fletcher, R.H.; O’Malley, M.S.; Earp, J.A.; Littleton, T.A.; Fletcher, S.W.; Greganti, M.A.; Davidson, R.A.; Taylor, J. Patients' priorities for medical care. Med. Care 1983, 21, 234-242. [CrossRef] [PubMed]

18. Egunjobi, L. Factors Influencing Choice of Hospitals: A Case Study of the Northern Part of Oyo State, Nigeria. Soc. Sci. Med. 1983, 17, 585-589. [CrossRef]

19. Donabedian, A. The quality of care: How can it be assessed? J. Am. Med Assoc. 1988, 260, 1743-1748. [CrossRef]

(C) 2019 by the authors. Licensee MDPI, Basel, Switzerland. This article is an open access article distributed under the terms and conditions of the Creative Commons Attribution (CC BY) license (http:/ / creativecommons.org/licenses/by/4.0/). 